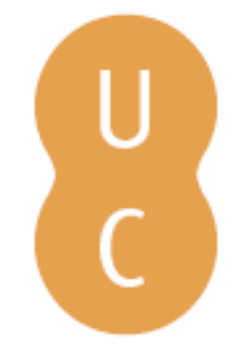

\title{
pommalina
}

\section{Time replacement optimization models for urban transportation buses with indexation to fleet reserve}

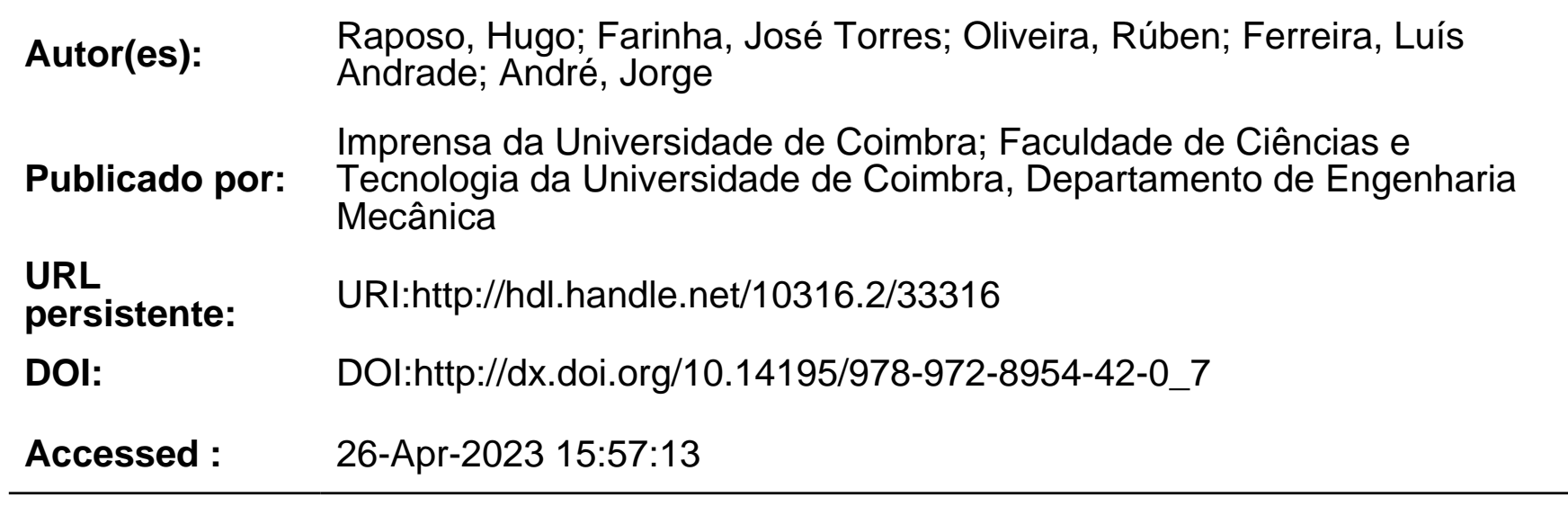

A navegação consulta e descarregamento dos títulos inseridos nas Bibliotecas Digitais UC Digitalis, UC Pombalina e UC Impactum, pressupõem a aceitação plena e sem reservas dos Termos e Condições de Uso destas Bibliotecas Digitais, disponíveis em https://digitalis.uc.pt/pt-pt/termos.

Conforme exposto nos referidos Termos e Condições de Uso, o descarregamento de títulos de acesso restrito requer uma licença válida de autorização devendo o utilizador aceder ao(s) documento(s) a partir de um endereço de IP da instituição detentora da supramencionada licença.

Ao utilizador é apenas permitido o descarregamento para uso pessoal, pelo que o emprego do(s) título(s) descarregado(s) para outro fim, designadamente comercial, carece de autorização do respetivo autor ou editor da obra.

Na medida em que todas as obras da UC Digitalis se encontram protegidas pelo Código do Direito de Autor e Direitos Conexos e demais legislação aplicável, toda a cópia, parcial ou total, deste documento, nos casos em que é legalmente admitida, deverá conter ou fazer-se acompanhar por este aviso.

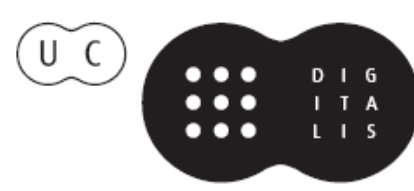




\title{
Time Replacement Optimization Models for Urban Transportation Buses with Indexation to Fleet Reserve
}

\author{
Hugo Raposo ${ }^{1}$, José Torres Farinha ${ }^{2}$, Rúben Oliveira ${ }^{3}$, Luís Andrade Ferreira ${ }^{4}$, Jorge André ${ }^{5}$ \\ hugrap@gmail.com ${ }^{1}$, torres.farinha@dem.uc.pt ${ }^{2}$, ruben.oliveira@dem.uc.pt ${ }^{3}$, lferreir@fe.up.pt ${ }^{4}$,jorge.andre@dem.uc.pt ${ }^{5}$ \\ $\mathrm{CEMUC}^{1,2,3}, \mathrm{FEUP}^{4}, \mathrm{UC}^{5}$ \\ Coimbra $^{1,2,3,5}$, Porto $^{4}$, Portugal $1^{1,2,3,4,5}$
}

\begin{abstract}
An efficient management of physical assets in general and the urban transportation buses in particular, has as objective the optimization of its Life Cycle Cost (LCC), being the optimization of its maintenance and the determination of the right moment of its withdrawal or its renewal, essential elements for optimization of the capital investments.
\end{abstract}

These aspects are related to the determination of the optimal dimension of the fleet reserve, aiming the maximization of its availability and the investment minimization. This can be reached through several algorithms that ought to be in consideration aspects like the maintenance costs, reseller cost, and inflation, among others.

This is reached trough the adequate maintenance policies, being these scheduled and or on-condition predictive or any kind of planned ones. This type of decisions are determinant to maximize the LCC and, by consequence, the dimension of reserve fleet.

It is through this perspective that the identification of the right moment of replacement or total renewal of an asset can be a strategic element in the competitiveness of the organizations by reducing the costs that can come from there.

The validation of the management models to be implemented will be done in the road transports sector of passengers' transportation and the models and the results have the potential to help this strategic sector in the global economy.

Keyword: Equipment Removal; LCC; Fleet reserve; On-Condition Maintenance; Scheduled Maintenance; Predictive Maintenance.

\section{INTRODUCTION}

The present article refers the replacement of buses, with indexation to the fleet reserve in companies of urban transportation buses.

In the present globalized economy, the companies' survival or, in a more generalized way, of the organizations depends on its ability to innovate. For that, they endlessly search new tools that may contribute for its continuous improvement.

The maintenance management or physical assets corresponds to a fundamental side for that goal. To guarantee the maximum availability of the equipment is a main goal of any maintenance section and this fact is determinant so that the companies are able to respond to the competitive challenges in which they are involved. A maintenance program that focus on the assets' management will only be successful if it stops to have an error management routine to the management of the life cycle of the assets.

The passenger transportation buses' management is an essential activity for the guarantee of the optimal compliance of its life cycle, which implies the combination of actions of management, technical and economical, in the sense of obtaining higher availability at rational costs, [1-5].

The cost of an asset's life cycle corresponds to the sum of all the spent capitals on the support of that asset since its conception and manufacturing, going through the operation until the end of its useful life [2]. It is understood that the useful lifetime goes until the deactivation of the equipment and that this could be different from the effective lifetime of the item, like it is the case of the equipment with fast technologic obsolescence.

The LCC of an asset can be significantly superior to the value of the initial investment and, in many cases, it's defined right on the project phase. [3]

The analysis of the cost of the life cycle it's a foreseeing and, therefore generally different methods are used in cost estimate, [7] and others like the Activity-Based Costing (ABC) [8]. The simulation method of Monte Carlo is another tool to deal with uncertainty.

To support the analysis of the cost of the life cycle there are rules as the referred in [9-10]. The rule about the assets management [11] is a good source of guidelines to the assets management that can be applied to any sector.

Though, the systematized study in this area remains underdeveloped, having the need of applying and creating new models of equipment management that can bring more benefits to the companies, in order to improve its productivity and quality of service, having in consideration the side of the environmental sustainability, including the rules of quality management, environment, safety, maintenance and energy [12], although it is known that many companies maintain equipment in function, even when its operation is no longer viable because they do not accompany its economic cycle , which has exogenous implications, in the case of passengers transportation, in the size of the fleet reserve.

According to [14], the traditional production systems are built over the scale economy principle. This author even 
illustrates a problem of equipment replacement, in a Lean Thinking context. [15] Says that the technological transformation as the motivation for replacement of the equipment. In scientific references is commonly assumed that technology continuously develops according to a well-defined function.

[16] Shows that combining continuous and discrete time models, the time to replace equipment is lower when the technology applied is superior.

According to [17], "the assessment of an profit is established by future benefits expected by cash flows referred to the present value by a discount rate that reflects the risk of the decision." Consequently, methods that consider the time value of money are the most suitable.

According to [18], the method of Equivalent Uniform Annual Cost CAUE is appropriate in the analysis of the company's operational activities, with investments that may repeat. Furthermore, the standardization of investment results equivalent to annual values makes the analysis of these results will easy the decision making. The use of this method is to determine what is the year with the lowest equivalent annual cost, which indicates the best time to replace the technical active [19].

The calculation of the equivalent annual cost is due to the use of the Capital Recovery Factor and it is through it that we can compare two or more investment opportunities and determining which ideal replacement of equipment time, taking into account information such as: value of the investment or acquisition; resale value or residual value at the end of each year; operating costs and cost of capital or minimum attractive rate [19].

The problem of determining the economic life of equipment for the purpose of replacing could be identified in four types of situation [20]:

1. When the good is already inadequate for the activity;

2. When the good has reached its limit of life;

3. When the good is already obsolete due to technological advances;

4. When more efficient methods show to be more economic.

In a certain point in the life cycle of a profit it is important to assess if keep it running or replaced. For this purpose, you must satisfy the following [12]:

i. Availability of new technologies;

ii. Fulfillment of safety standards or other mandatory;

iii. Availability of spare parts;

iv. Obsolescence that may limit its use.

After the listed aspects of the last point of the life cycle of the equipment, it is important to charactherize some calculation methods for determining the appropriate time to replace it. For this purpose it is necessary to take into account several variables:

- acquisition value

- Value of expiration

- operating costs

\section{- Inflation rate}

- Maintenance costs

O Operating Costs

- Capitalization rate

The majority of previous values of the variables are obtained by history, with the exception of the value expiration. In this case, to get the market value for each particular equipment, that can be not easy for many goods. An alternative it can simulate several types of devaluation such as the following [21]:

- Linear method of depreciation - the decline of the value of the equipment is constant over the years.

- Method of the sum of digits - the annual depreciation is not linear.

- Exponential method - The annual depreciation charge is decreasing over the life of the equipment.

Another method commonly used is the "lifetime" that defines that ends when the maintenance costs exceed the costs of maintenance plus the amortization of the capital of equivalent new equipment. According to [12] there are several methods for determining the economic cycle equipment replacement. The most common are:

- Method of Uniform Annual Rent (MUAR);

- $\quad$ Method of Minimizing Total Average Cost (MCMT);

- MCMT method with the reduction of the present value (MCMT-PVR);

In [22], illustrates the effective use of fixed assets as a major objective in the management of companies in the urban passenger transport sector.

Companies in the urban transport sector, the efficient use of profits is linked to a well-structured policy assessment and fleet replacement. Some cases of fleet replacement applied to the city bus segment are reported in [22-25].

The adoption of a single decision criteria is restrictive, given that costs, efficiency and level of service should be evaluated simultaneously. Methods such as Multi Attribute Utility Theory (MAUT), Analytical Hierarchy Process (AHP) and Quality Function Deployment (Quality Function Deployment - QFD) have been used to accommodate multiple decision makers and multiple decision criteria. However, were not found in the literature approaches consolidated using these methods in the replacement of public transport vehicles. It is also referred the use of stochastic models in conjunction with neural networks to model the creation of a replacement vehicle.

[26] Presents a proposal of a generic stochastic process model based on neural networks called Stochastic Neural Process (NSP) that can be applied in problems involving stochastic phenomena or periodic behavior and characteristics. Through neuronal networks of the PEN models the behavior of the time series of these phenomena without requiring a priori information about the series, by generating synthetic time series equally adaptable to the historical series. Some cases of using neural networks and stochastic models are reported in the literature [27-33]. 


\section{BUSES REPLACEMENT MODELS}

The replacement of equipment is an umbrella concept that embraces selection of similar profits, but new ones, to replace the existing ones, to evaluate the profits that act in ways completely different performance of the same function. This is the case of obsolete buses may be replaced by new models that operate in a similar manner.

Replacement decisions are critical for the company, because they are generally irreversible, ie, have no cash and require large amounts of money.

There are several reasons to make economic action to do the replacement of equipment. The deterioration is one of the causes, and is manifested by excessive operating costs and by the increasing of the maintenance costs. There are situations here the replacement of a standard operation conduce to the loss of the device ability to operate efficiently, ie, it becomes inappropriate.

Importa fazer a caracterização de métodos de cálculo adequados para determinação da altura adequada à substituição dos autocarros de transporte urbano de passageiros. Para o efeito, é necessário ter em consideração diversas variáveis:

So it is important perform a characterization of the appropriate methods of calculation for determining the proper time of replacement of buses for urban passenger transport. Indeed it is necessary to take in account several variables:

- Cost of acquisition (CA)

- Value of expiration (VC)

- The operating costs (EC)

- Maintenance costs $(\mathrm{CM})$

- Operating costs $(\mathrm{CO})$

- inflation rate $(\Theta)$

- capitalization rate (i)

The majority of previous values of the variables are obtained by history, with the exception of the value expiration. In this case, to get the market value for each particular equipment, that can be not easy for many goods. As an alternative it can simulate several types of devaluation such as the following: [21]

- Linear depreciation method- that lies on the assumption that the decline of the value of the equipment is constant over the years.

- Method of the sum of the digits - the annual depreciation is not linear.

- The Exponential method - The annual depreciation charge is decreasing over the life of the equipment.

\section{A. Linear Depreciation Method}

This method assumes that the decrease in the value of the device is constant over the years and is calculated by the following formula:

$$
d_{j}=\frac{C A-V C_{n}}{N}
$$

$\mathbf{d}_{\mathbf{j}} \quad$ Annual depreciation quota

CA Acquisition cost of equipment
$\mathbf{V C}_{\mathbf{n}}$ Residual value of the equipment at the end of $\mathrm{N}$ periods

N Lifetime corresponds to

j $\quad \mathrm{j}=1,2,3 \ldots \mathrm{n}$

$\mathbf{V}_{\mathbf{n}} \quad$ Value of the equipment over a period $\mathrm{n}=1,2,3 \ldots \mathrm{n}$. by:

The value of the equipment $\mathrm{V}_{\mathrm{n}}$, in a period $\mathrm{n}$ lower $\mathrm{N}$ is given

$$
V_{j}=C A-j * d
$$

\section{B. Method of Sum of Digits}

In this method, the annual depreciation is not linear and is calculated the following way:

$$
\begin{gathered}
d_{j}=2 * \frac{N-(j-1)}{N+1} * \frac{C A-V C_{n}}{N} \\
V_{n}=C A-d_{j}
\end{gathered}
$$

\section{Exponential Method}

The exponential method emphasizes an annual depreciation that decreases over the life of the equipment. The calculation formula is as follows:

$$
\begin{gathered}
d_{j}=V C_{j-1} *\left(1-\sqrt[N]{\frac{V C_{n}}{C A}}\right) \\
V_{n}=C A-d_{j}
\end{gathered}
$$

According to [12] the equipment can be replaced by various criteria. The financial aspect, a usual criterion is the "economic cycle" which determines the optimal period which minimizes the average total costs of operation, maintenance and capital immobilization.

Another method commonly used is the "lifetime" that defines that the equipment ends when their maintenance costs exceed the costs of maintenance plus the amortization of the capital of equivalent new equipment.

However, despite being possible from the depreciation values of market power pass to the analysis of equipment replacement, should be taken into account two other variables, which are:

- The capitalization rate, called for $\mathrm{i}$

- The inflation rate, called by $\theta$

These rates are related as follows:

$$
i_{A}=i+i+\theta \times \theta
$$

According to [12] there are several methods for determining the economic cycle equipment replacement. The most common are:

- Method of Uniform Annual Income (MRAU)

- Method of Minimizing Total Average Cost (MCMT) 
- MCMT method with the reduction of the present value (MCMT-PVR)

This article will use the Uniform Method of Annual Income (MRAU), this makes use of the following data:

- Acquisition cost of equipment

- $\quad$ expiration values (calculated according to the methods exposed ago)

- Maintenance Costs and Exploration over the years

- Apparent rate

D. Net present value in year $n$ (VPLn)

$$
V P L_{n}=C A+\sum_{j=0}^{n} \frac{C M_{j}+C O_{j}}{\left(1+i_{A}\right)^{j}}-\frac{V_{n}}{\left(1+i_{A}\right)^{j}}
$$

With,

CA Acquisition cost of equipment

$\mathbf{C M}_{\mathbf{j}} \quad$ Maintenance costs in year $\mathrm{j}=1,2,3 \ldots . \mathrm{n}$

$\mathbf{C O}_{\mathbf{j}} \quad$ Operating costs in year $\mathbf{j}=1,2,3 \ldots . n$

$\mathbf{i}_{\mathbf{A}} \quad$ Apparent rate

$\mathbf{V}_{\mathbf{n}} \quad$ Value of the equipment over a period $\mathrm{n}=1,2,3 \ldots \mathrm{n}$.

E. Uniform Annual Rent (RAUn)

$R A U_{n}=\frac{i_{A}\left(1+i_{A}\right)^{j}}{\left(1+i_{A}\right)^{j}-1} *\left(C A+\sum_{j=0}^{n} \frac{C M_{j}+C O_{j}}{\left(1+i_{A}\right)^{j}}-\frac{V_{n}}{\left(1+i_{A}\right)^{j}}\right)$

$$
R A U_{n}=\frac{i_{A}\left(1+i_{A}\right)^{j}}{\left(1+i_{A}\right)^{j}-1} * V P L_{n}
$$

With,

$\mathbf{V P L}_{\mathbf{n}} \quad$ Net present value $\mathrm{n}=1,2,3 \ldots \mathrm{n}$

The minor RAU calculated value indicates the respective period (multi-year), in which the equipment must be replaced. This value is equivalent to a minimum income that the equipment would cost annually.

The MCMT determines the lowest average cost of ownership of the equipment and the respective it occurs that corresponds to the optimal time of replacement. They are not considered capital costs and the rate of inflation. The calculation procedure is as follows:

$C_{n}^{\prime}=\frac{\sum_{j=0}^{n} C M_{j}+C O_{j}}{n} \quad C_{n}=\frac{C A-V_{n}}{n} \quad C_{n}=C_{n}^{\prime}+C_{n}^{\prime \prime}$

With,

n Number of years $n=1,2,3 \ldots \mathrm{n}$

$\mathbf{C}_{\mathbf{n}} \quad$ Average total cost

The MCMT - RVP the calculation procedure is identical to the previous one, with the exception that are considered capital costs and the inflation rate. The various values of maintenance and disposal, over the years, are reduced to present value, according to the following procedure:

$C_{n}^{\prime}=\frac{1}{n} \sum_{j=1}^{n} \frac{C M_{j}+C O_{j}}{\left(1+i_{A}\right)^{j}} C_{n}^{\prime \prime}=\frac{C A-\frac{V_{n}}{\left(1+i_{A}\right)^{j}}}{n} C_{n}=C_{n}^{\prime}+C_{n}^{\prime \prime}$

\section{APPLICATION OF THE MODEL IN THE TRANSPORT SECTOR}

The demonstrational application of the equipment replacement model will be made then in the road transport sector, with an emphasis on passenger, which corresponds to a strategic sector of the national and global economy. Application of the Model in the Transport Sector

The aim of this paper to present a model replacement bus passenger transport leading to the rationalization of the reserve fleet in a global perspective, to create integrated models that allow:

- Optimizing the management of their lifecycle;

- Optimizing the time of replacement;

- Optimizing the fleet reserve.

To develop this study and the fulfillment of the objectives listed in the previous paragraph, should be taken into consideration variables related aspects such as the technological aspects, the duly itemized direct operating costs, downtime costs, as well as indicators economic applicable, such as inflation and interest rates, among others.

In the first phase of the data collection operation for preparation of LCC is made, a road transport company. Based on these data is initiated the development of simulation models from a small number of buses, taken as a pilot to validate the replacement model.

\section{A. Characterization of buses}

In this phase the variables relevant to the purpose have been defined such as: Operation, maintenance, service user and the environment. Further characterize aspects that significantly affect the operating performance of the buses (existence and type of air-conditioning, engine power, etc.).

In the preparation of the models the following variables were used: the year of manufacture of the buses; starting year of operation; trademark; model; type of vehicle; maintenance costs; cost of operation; etc.

10 cars divided into two brands and five different models of buses, as shown in Table 1 were selected.

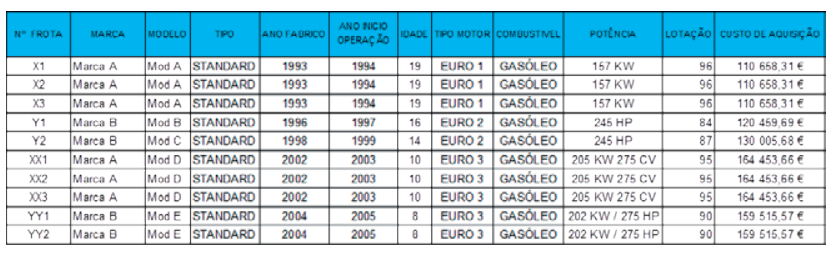

Fig. 1. Table Characteristics of Buses

\section{B. Background data of Buses}

At this stage, the focus corresponds to the identification and collection of primary data that are the basis for the analysis. The data should be relevant to the description of fleet costs and related activities, and should support the understanding of strategic economic and business information. Should be given priority to the information concerning procedures of operation, maintenance and planning. In this context, the historical data 
for each vehicle target of the study were collected, as can be seen below in Tables 2-6.

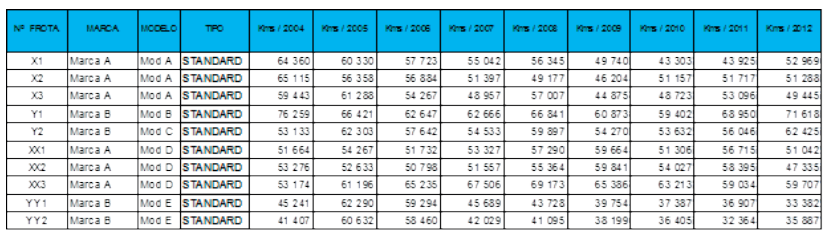

Fig. 2. Table Kms / year traveled by bus

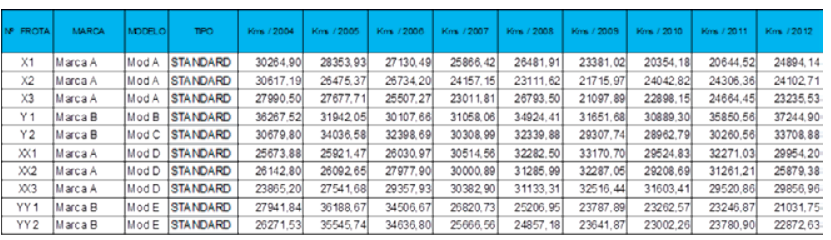

Fig. 3. Table of Litres of Fuel consumed / year by bus

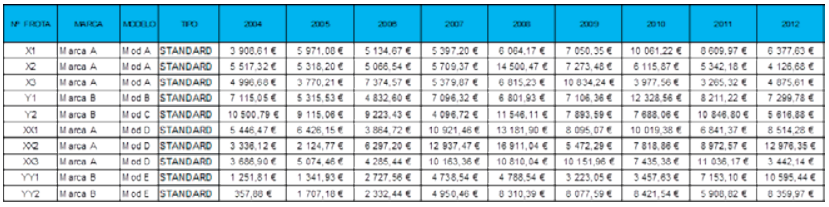

Fig. 4. Table of Operating Costs

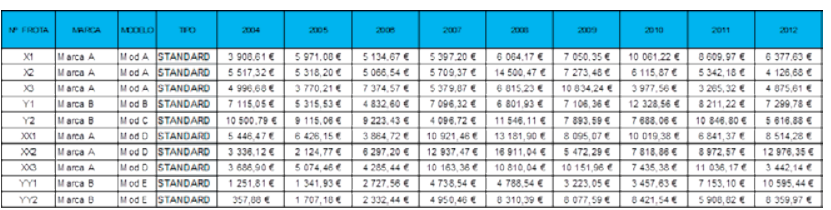

Fig. 5. Table of Maitenance Costs

\begin{tabular}{|c|c|c|c|c|c|c|c|}
\hline N FROTA & MARCA & MODED & TRO & 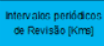 & duscíns & 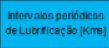 & P \\
\hline $\mathrm{x} 1$ & MarcaA & Mod A & STANDARD & 30000 & $A 1, A 2, A 1 A 3, A 1, A 2$ & 25000 & L2.L4L2.L4 \\
\hline$x_{2}$ & MarraA & Mod A & STANDARD & 30000 & $\mathrm{~A} 1 \mathrm{~A} 2 \mathrm{~A} 1 \mathrm{~A}, \mathrm{~A} 3 \mathrm{~A} 1 \mathrm{~A} 2$ & 25000 & $12.4,12,14$ \\
\hline$\times 3$ & MarraA & ModA & STANDARD & 30000 & $\mathrm{~A} 1 \mathrm{~A} 2 \mathrm{~A} 1 \mathrm{~A}, \mathrm{~A} 3 \mathrm{A1}, \mathrm{A} 2$ & 25000 & L2.L4.L2.L4 \\
\hline $\mathrm{Y} 1_{1}$ & Marta $B$ & Mod B & STANDARD & 20000 & $\mathrm{~A} 1 \mathrm{~A} 2 \mathrm{~A} 1 \mathrm{~A}, \mathrm{~A}, \mathrm{A1} 1 \mathrm{A2} 2$ & 15000 & L2.L3.L2.L4 \\
\hline $\mathrm{Y} 2$ & Marra B & Mod C & STANDARD & 20000 & $\mathrm{~A} 1, \mathrm{~A} 2, \mathrm{~A} 1, \mathrm{~A} 3, \mathrm{~A} 1, \mathrm{~A} 2$ & 15000 & $2, L 3, L 2, L 4$ \\
\hline$x \times 1$ & Marra $\mathrm{A}$ & Mod D & STANDARD & 50000 & $A 1, A 2, A 3, A 1, A 2, A 3$ & 50000 & $2, L 3, L 2, L 4$ \\
\hline$x \times 2$ & Marca A & Mod D & STANDARD & 50000 & $A 1, A 2, A 3, A 1, A 2, A 3 \ldots$ & 50000 & L2.L3.L2.L4. \\
\hline$\times \times 3$ & Marra A & Mod D & STANDARD & 50000 & $A 1, A 2, A 3, A 1, A 2, A 3 \ldots$ & 50000 & L2.L3.L2.L4. \\
\hline$w_{1}$ & Marca $B$ & Mod E & STANDARD & 25000 & $A 1, A 2, A 3, A 1, A 2, A 3$ & 15000 & L2.L3.L2.L3.L2.L4 \\
\hline $\mathrm{Y} 2$ & Marca B & Mod E & STANDARD & 25000 & $A 1, A 2, A 3, A 1, A 2, A 3$ & 15000 & $L 2, L 3, L 2, L 3, L 2, L 4$ \\
\hline
\end{tabular}

Fig. 6. Intervals and systematic preventive maintenance schedule

In the next section will be analyze the method of Uniform Annual Rent (RAU) for determining the economic cycle of buses replacement, we are analyzing a company in the sector of urban transport. Table 7 presents the values related to Linear Depreciation Method, Table 8 the method of Sum of Digits, and Table 9 the Exponential Method.

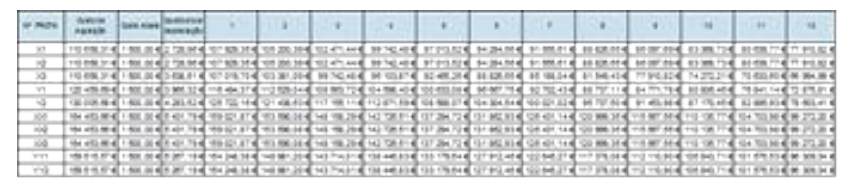

Fig. 7. Linear depreciation method Styling

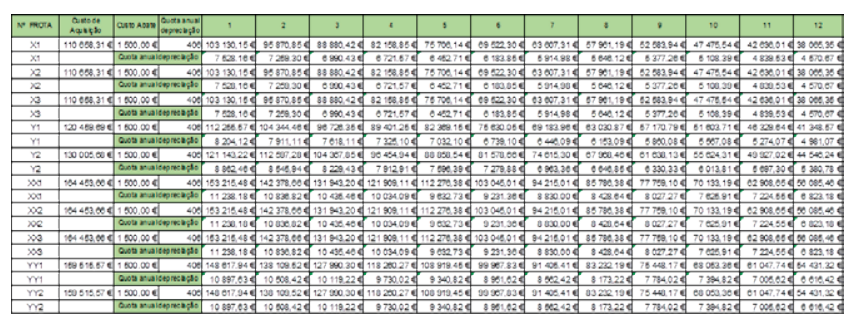

Fig. 8. Method of Sum of Digits

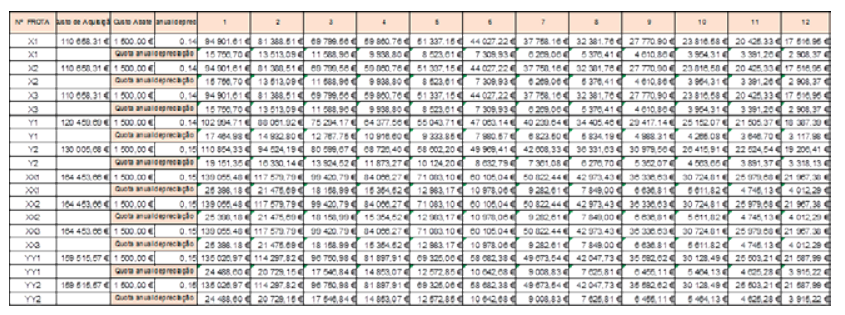

Fig. 9. Exponential Method

\section{The application the Method of Uniform Annual Rent (RAU)}

For the application of UARM we used historical data for a group of vehicles. These were grouped into homogeneous groups, in a period between 1993 to 2012 it were studied the vehicles with 19,16,14,10 and 9 years were studied. Table 10 shows the calculation of Annual Income Uniforms for homogeneous group: Brand A, Model A, with three cars of 19 years. We also analyzed data of buses designated as X2 and $\mathrm{X} 3$, the results are shown in Figures 11 to 13.

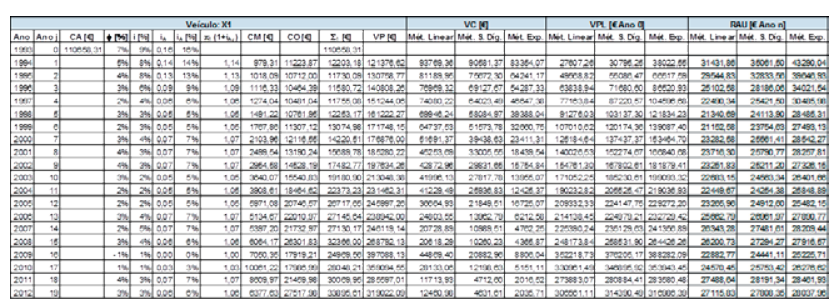

Fig. 10. Tablet RAU - Bus X1

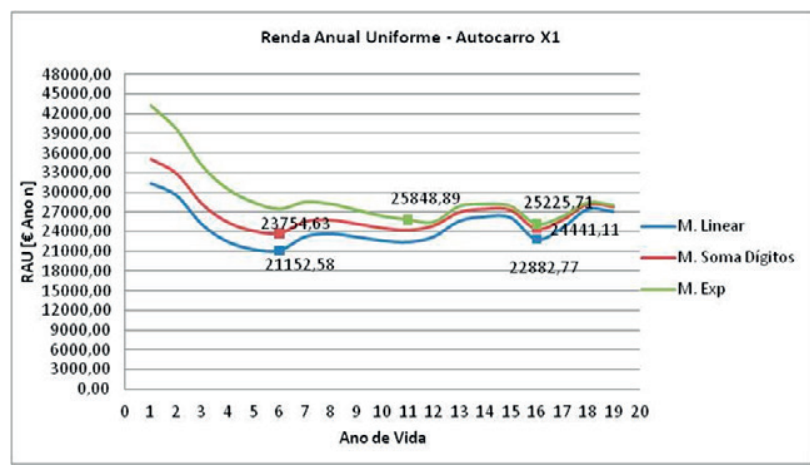

Fig. 11. Grafic RAU - Bus X1 


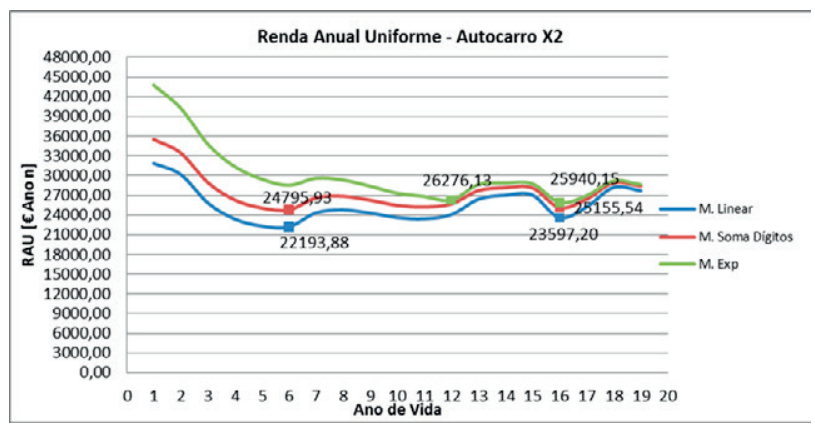

Fig. 12. Grafic RAU - Bus X2

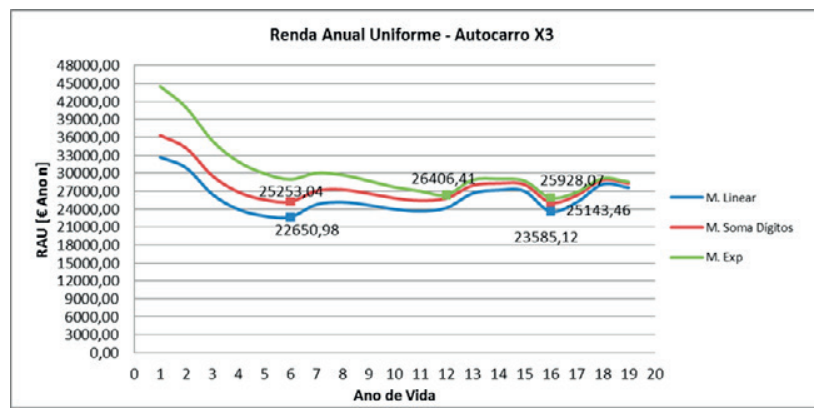

Fig. 13. Grafic RAU - Bus X3

Through the analysis of previous data can be seen that the values of rents vehicles are very similar. On Table 10 and the Depreciation Method Exponential it appears that the Uniform Annual Cost is minimal between the twelfth and the sixteenth year (economic life), with an approximate value of $€ 25,000 /$ year.

The minor RAU calculated value indicates the respective period (multi-year) in which the equipment must be replaced. This value is equivalent to a minimum income that the equipment would cost annually. It can be concluded that this period corresponds to the ideal time to proceed to the replacement of buses based on the Exponential Method for depreciation. If the methods of depreciation are used and the Linear Sum of Digits it appears that the RAU values decrising; however there is an increase in the period where the value of RAU is minimal, that is between the sixth and the sixteenth, that creat problems to the decision of the ideal moment to replace the equipment.

We can then verify the calculation of Uniform Annual Rent for homogeneous group: B Brand, Model B and C, consisting of two cars of 16 and 14 years (Table 14 and 15).

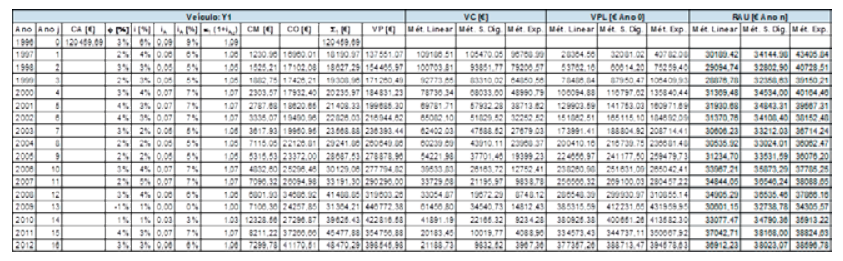

Fig. 14. Tablet RAU - Bus Y1

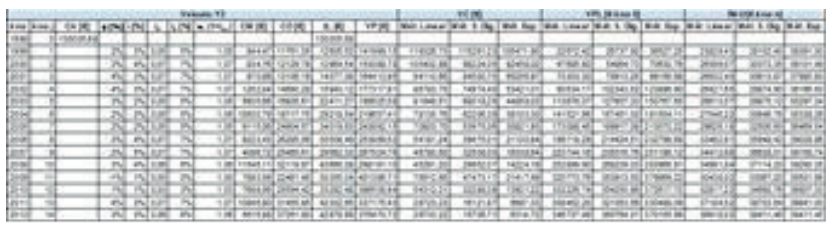

Fig. 15. Tablet RAU - Bus Y2

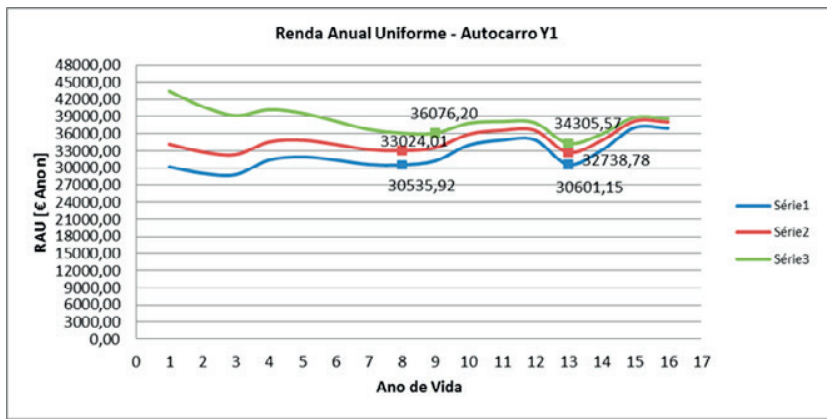

Fig. 16. Grafic RAU - Bus Y1

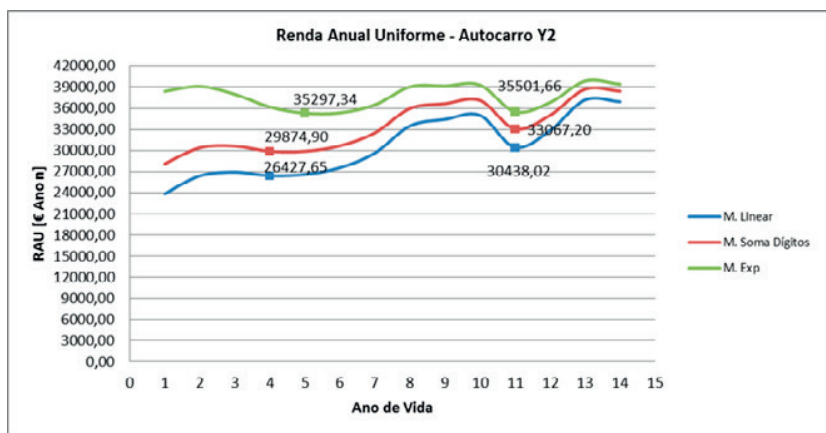

Fig. 17. Grafic RAU - Bus Y2

Through the analysis of charts of RAU of the buses Y1 and Y2 can be seen that the values of rents vehicles are not identical.

In relation to vehicle $\mathrm{Y} 2$ is verified that the RAU will be minimal between the fourth and eleventh years (economic life), with an approximate value of $€ 35,000$ / year.

If the methods of depreciation and Linear Sum of Digits are used can be seen that the RAU values decrease, but occurs an increase of one year in the period where the value of RAU is minimal, which produce problems in the taking of decision of the best time to proceed to the replacement of the equipment.

The Table 18 illustrates the calculation of the RAU to the bus XX1 of the homogeneous group: Brand A, Model B, composed of three vehicles of 10 years; Figures 19 to 20 illustrate the evolution of RAU for XX1, XX2 and XX3.

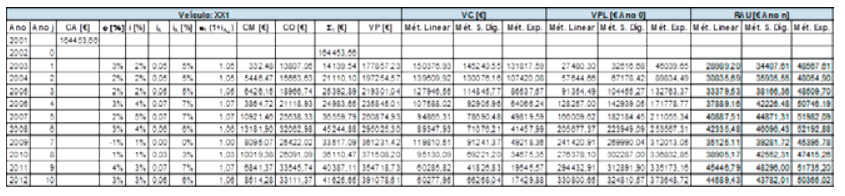

Fig. 18. Tablet RAU - Bus XX1 


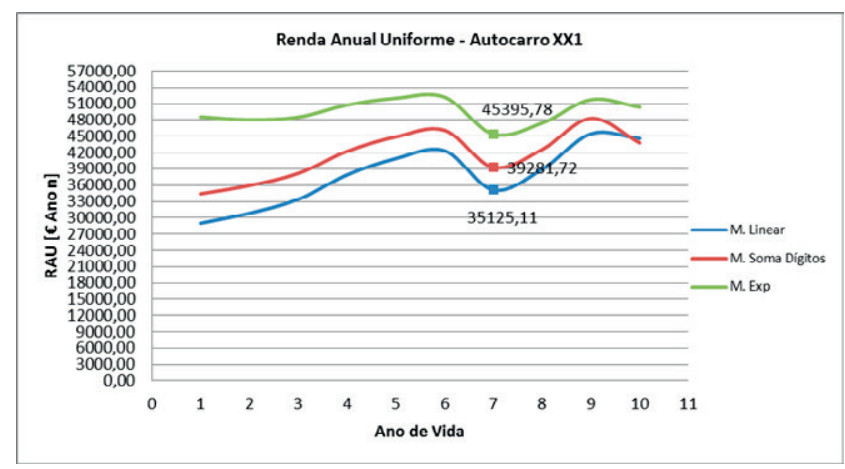

Fig. 19. Grafic RAU - Bus XX1

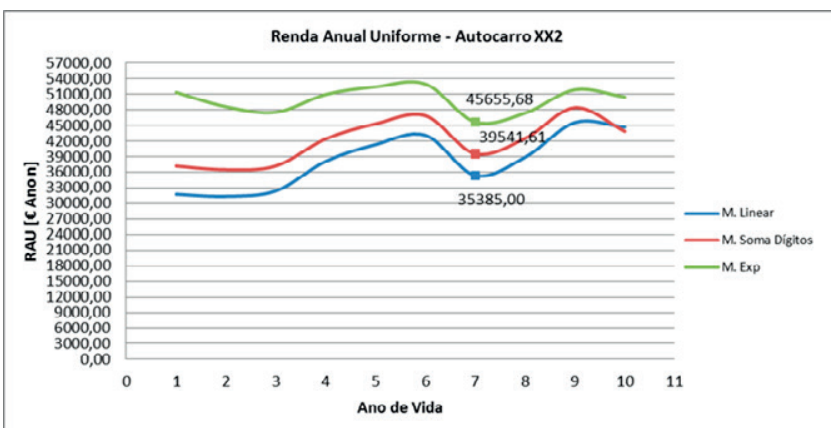

Fig. 20. Grafic RAU - Bus XX2

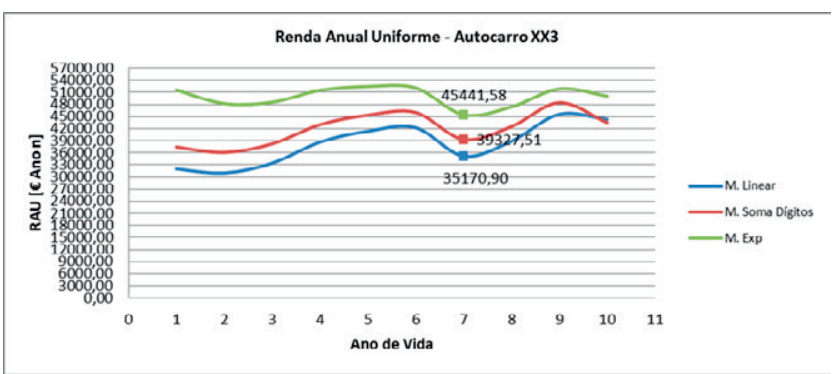

Fig. 21. Grafic RAU - Bus XX3

By the data showed it appears that the replacement period varies from homogenous group to homogeneous group of vehicles and there are several variables that can influence the outcome and the final decision of the manager, such as the apparent rate of each year as well as the depreciation model used. Another very important variable that can significantly influence the results is the maintenance cost. This, in turn, depends heavily on the policies and management of maintenance that is performed at public transport companies.

\section{CONTRIBUTIONS TO THE FLEET RESERVE}

The urban transport companies always have a given rate of buses reservation, which varies from company to company. A low reserve ratio is a synonym of high reliability, relying essentially on implementation of an efficient planned maintenance, which results in the application of new methods and maintenance techniques that lead to the assessment of the state of the equipment and the decision of replacing or renewing the equipment's.
There is a common set of factors that affect the optimal size of the number of vehicles in a reserve fleet, that are:

- Composition of the bus fleet;

- Brands and models;

- Age of the fleet;

- Annual rolling of the buses;

- Commercial speed that buses are subject;

- Surrounding and the operating environment;

- Daily fluctuations in the demand for transport;

- Policies and maintenance plans;

- Ratio of vehicles per mechanic;

- Planes maintenance training;

- Number of interventions picket;

- Tunings introduced the routes;

- Tunings introduced in services;

- Inventory management;

- Administration and Finance

To assess the management practices in transport companies the FTA (Federal Transit Administration - USA) conducted a survey of the 36 North American and Canadian companies, which included eight small companies with fleets of between 33 and 199 buses eight medium enterprises with fleets between 225 and 472 bus, 12 large companies with fleets ranging between 537 and 963 buses and eight very large companies with fleets between 1009 and 3664 buses. A synthesis of indicators of activity distributed by classes can be analyzed in Table 22.

\begin{tabular}{|c|c|c|c|c|c|}
\hline Clanse & $\begin{array}{c}\text { Nimerer de } \\
\text { Sapreas }\end{array}$ & 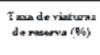 & 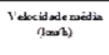 & 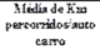 & 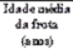 \\
\hline Syotene & $\varepsilon$ & 19 & 260 & $5+65$ & $\%$ \\
\hline Bobs & 8 & 22 & 30,6 & 5950! & 81 \\
\hline Gavest & 12 & 21 & 264 & $6 K 566$ & 8 \\
\hline $\begin{array}{l}35+\infty \\
192,4\end{array}$ & $s$ & 17 & 19,3 & $6 \mathrm{2m} 1$ & 3,3 \\
\hline 2000 & 36 & 20 & 20,3 & 61241 & 8,3 \\
\hline
\end{tabular}

Fig. 22. Indicators of operating fleets, according to their size

The measurement and monitoring of reserve rates continue to be an important management tool in the urban transport sector. The inquire results highlight that transport managers are aware of their responsibility in the management of fleets within reasonable constraints of rolling materials reserve.

Survey responses indicate that efforts are being made in the sector to find ways to reduce the number of units vehicles spares. Many maintenance managers not only follow the guidelines of the FTA regarding the target of $20 \%$ of vehicle spares, as they have adopted the philosophy of "the smaller the better" in the managing of their fleets.

Ten percent of the buses are in daily standard repairs. On average, each bus of external service uses the pickets intervention nine times a year. The combined effects of the restrictive legislation of pollution in California, the dedicated maintenance, the high demand of transports and a skewed distribution on age and type of the impact of bus effects have led to an increased rate of reserve vehicles.

As a corollary, it may be noted that the definitions of the indicators of management of urban passenger transport shift 
from company to company. It also appears that the technologies used, the accuracy and frequency of collection of values of operating variables and indicators of buses network, the methodology and handle of the data vary significantly from operator to operator.

. In urban transport companies there is a great diversity of reserve rates of vehicles, which seems to show empiricism in its determination. It is therefore important to study this discrepancy in terms of optimizing an integrated model of replacement that necessarily implies a rationalization in the reserve fleet. Intends to implemented mathematical modeling of final decision support for replacement of buses of a fleet indexed to the reserve buses fleet. This model will be validated in all is extension in an enterprise of collective to transports not only with the aim of the validation, but also to incorporate the goods of the contributions of the managers who will use it.

\section{V.CONCLUSIONS}

This article presents a new approach to the economic models to the determination of the most adequate time for a replacement of buses in a urban fleet of an enterprise. The economic aspects were defined in concordance with the pertinent indicators and the cash flow, driven by the cost associated to the acquisitions, maintenance, and operation, among others.

The study presented allows the equipment's life cycle assessment by the managers and obviously it is a decision support tool.

It was demonstrated in the study that exist a variation of ideal moment for as replacement of a vehicle of a fleet, given by the analyses performed by the model of the annual uniform lease. Despite this still to be an anchor point and a useful tool to be used in future models that support the better take of decision. This new models should take in account not only the economics criteria but also non-economics as strategic and management assessed by the multy-dicision tools.

The new model should allow a detailed assessment of the present buses performance against the potential substitutes that turn viable a constant motorization of the goods of the enterprise and keeping high levels of quality and satisfaction of the customer service.

\section{REFERENCES}

[1] Aoudia, M.; Belmokhtar, O., (2008): Economic impact of maintenance management ineffectiveness of na oil gas company. Journal of Quality in Maintenance Engineering, Vol. 14, nº 3, pp. 237-261.

[2] Assis, R., (2010): Apoio à decisão em manutenção na gestão de activos fisicos. Lisboa: $1^{\text {a }}$ Edição, Lidel - Edições técnicas, Lda.

[3] Assis R.; Julião, J. (2009): Gestão da Manutenção ou Gestão de Activos? (custos ao longo do Ciclo de Vida). Comunicação $10^{\circ}$ Congresso Nacional Manutenção, APMI, Figueira da Foz, Portugal.

[4] Bescherer, F (2005): established Life Cycle Concepts in the Business Environment - Introductionand terminology, Laboratory of Industrial Management Report Series, report 1/2005, Helsinki University.

[5] Lindholm, A. and Suomala, P (2004): "The possibilities of Life Cycle Costing in Outsourcing Decision Making”. Frontiers of E-Business Research 2004.

[6] Korpi, E. and Ala-Risku, T. (2008), Life cycle costing: a review of public case studies. Managerial Auditing Journal, Vol. 23, N. 3, pp. 240-61.

[7] Durairaj, S.K., et al. (2002), Evaluation of life cycle cost analysis methodologies, corporate Environment Strategy, Vol. 9 N. 1, pp. 30-9.

[8] Emblemsvag, J. (2001), Activity-based life-cycle costing. Managerial Auditing Journal, Vol. 16, N. 1, pp. 17-27.

[9] International Electrotechical Commissioning (2004), IEC 60300-3-3: Dependability management - Part 3-3: life cycle cost analysis - Application Guide, Chicago, II.

[10] ASTM International (2002), Standard practice for measuring life-cycle costs of buildings and buildingsystem. Annual Book of ASTM Standards: 2002, Vol. 4, ASTM International West Conshohocken,PA, E 917, No. 11.

[11] BAS PAS 55 (2008), Asset Management: PAS 55-1, Part 1: Specification for the optimized managementof physical assets | PAS 55-2, Part 2: Guidelines for the application of PAS 55-1. British Standards, UK.

[12] Farinha, J. M. T. (2011): Manutenção - A Terologia e as Novas Ferramentas de Gestão. Lisboa: $1^{\text {a }}$ Edição, Monitor - Projecto e Edições, Lda.

[13] Oliveira, J. A. N. (1982), Engenharia Económica - Uma abordagem às Decisões de Investimento, São Paulo: McGraw-Hill do Brasil.

[14] William, G. S.; Thomas, N. M.; Eileen M. V. A. (2002): Equipment replacement decisions and lean manufacturing. ELSEVIER.

[15] Jennifer, L. R. and Joseph C. H. (2005): Equipment replacement under continuous and discontinuous technological change. IMA Journal of Management Mathematics; Volume 16, Issue 1.

[16] Natali, H.; Yuri Y. (2007): Optimal equipment replacement without paradoxes: A continuous analysis. Operations Research Letters. ELSEVIER. Volume 35, Issue 2, March, Pages 245-250

[17] Assaf Neto, A. (2005): Finanças corporativas e valor. São Paulo: Atlas.

[18] Casarotto Filho, N. (2000): Análise de investimentos - matemática financeira, engenharia económica, tomada de decisão, estratégia empresarial. \&ndash; 9.ed. \&mdash; São Paulo: Atlas.

[19] Vey, I. H.; Rosa, R. M. (2004): Substituição de frota em empresa de transporte municipal de passageiros: um estudo de caso. Universidade Federal de Santa Maria.

[20] Motta, R. R.; Calôba, G. M. (2002): Análise de investimentos: tomada de decisão em projetos industriais. São Paulo: Atlas.

[21] Oliveira,J. A. N. (1982), Engenharia Económica - Uma abordagem às Decisões de Investimento, São Paulo: McGraw-Hill do Brasil.

[22] Feldens, A. G.; Muller, C. J.; Filomena, T. P.; Neto, F. J. K.; Castro, A. S.; Anzanello, M. J. (2010): Política para Avaliação e Substituição de Frota por Meio da Adoção de Modelo Multicritério. Porto Alegre, Brazil, ISSN 1980-4814.

[23] Pinar, K.; Hartman, J. (2004), Case Study: Bus Fleet Replacement. The Engineering Economist, 49(3): 253-278.

[24] Khasnabis, S.; Alsaidi, E.; Ellis, R. (2002),Optimal allocation of resources to meet transit fleet requirements. Journal of Transportation Engineering, 128(6): 509-518.

[25] Di, J.; Hauke, L. (2000), Optimal fleet utilization and replacement. Transportation Research Part E, 36E(1): 3 .

[26] Campos, L. C. D.; Vellasco, M. M. B. R.; Lazo, J. G. L. (2010): Um modelo estocástico baseado em redes neurais. UFJF, Juiz de Fora, Brazil.

[27] Amaya, E. J.; Tonaco, R.;Souza, R. Q.; Álvares, A. J. (2007): Sistema Inteligente de Manutenção Baseada em Condição para Usina Hidrelética de Balbina. Universidade de Brasília, Departamento de Engenharia Mecânica e Mecatrônica, Grupo de Inovação em Automação Industrial (GIAI), CEP 70910-900, Brasília, DF, Brasil.

[28] Figueiredo, L. M. J. (2009): Modelo multicritério de apoio à substituição de equipamentos médicos hospitalares, IST, Lisboa, Portugal.

[29] Zhao, H. (2009). A chaotic time series prediction based on neural network: Evidence from the shanghai composite index in china. In Test and Measurement, 2009. ICTM 09. International Conference on, volume 2, pages $382-385$.

[30] Luna, I., Ballini, R., and Soares, S. (2006). Técnica de identificacão de modelos lineares e não-lineares de séries temporais. Revista Controle e Automacão, 17(3):245-256.

[31] Múller, D. (2007). Processos Estocásticos e Aplicacões, volume Coleccão Económicas -

2. ${ }^{\text {a }}$ Série of Direito Financeiro E Tributário. Almedina.

[32] Marco, A. R.; Angelo, A. D.; Leizer, S.; Silvio, A. B. V. (2010): A utilização de redes Bayesianas no processo decisório de de intervenções em equipamentos. Programa de Engenharia Industrial, Universidade Federal da Bahia, Escola Politécnica, Federação, 40.210-630, Salvador, Brasil.

[33] Araujo, M. S.; Bezerra, C. A.(2004): Desenvolvimento de componentes para sistemas estocásticos de apoio à decisão. PUCPR, Congresso Brasileiro de Computação, Engenharia Software, Brasil. 